\title{
Transfer Constants for Blood-Brain Barrier Permeation of the Neuroexcitatory Shellfish Toxin, Domoic Acid
}

\author{
Edward Preston and Ivo Hynie
}

\begin{abstract}
The cause of the toxic mussel poisoning episode in 1987 was traced to a plankton-produced excitotoxin, domoic acid. Experiments were undertaken to quantitate the degree to which blood-borne domoic acid can permeate the microvasculature to enter the brain. Pentobarbital-anesthetized, adult rats received an i.v. injection of ${ }^{3} \mathrm{H}$-domoic acid which was permitted to circulate for 3-60 min. Transfer constants (Ki) describing blood-to-brain diffusion of tracer were calculated from analysis of the relationship between brain vs plasma radioactivity with time. Mean values (mL.g$\left.{ }^{1} . \mathrm{s}^{-1} \times 10^{6}\right)$ for permeation into 7 brain regions $(n=10$ rats) ranged from $1.60 \pm 0.13$ (SE) to $1.86 \pm 0.33$ (cortex, ponsmedulla respectively), and carrier transport or regional selectivity in uptake were not evident. Nephrectomy prior to domoic acid injection resulted in the elevation of circulating plasma tracer level and brain uptake. The $\mathrm{Ki}$ values are comparable to those for other polar compounds such as sucrose, and indicate that the blood-brain barrier greatly limits the amount of toxin that enters the brain. Together with absorbed dosage, integrity of the cerebrovascular barrier and normal kidney function are important to the outcome of accidentally ingesting domoic acid.
\end{abstract}

\begin{abstract}
RÉSUMÉ: Constante de transfert pour la pénétration de la barrière hémo-encéphalique par la toxine neuroexcitatrice provenant de mollusques, l'acide domoïque. La cause de l'épisode d'empoisonnement par une toxine provenant de mollusques en 1987 a été retracée à une toxine excitatrice produite par un plancton, l'acide domoïque. Des expériences ont été réalisées pour quantifier à quel degré l'acide domoïque véhiculée par le sang peut infiltrer la microvasculature pour pénétrer dans le cerveau. Des rats adultes anesthésiés au pentobarbital ont reçu une injection intra-veineuse d'acide domoïque marquée au tritium qu'on laissait circuler pendant 3 à 60 minutes. Les constantes de transfert (Ki) décrivant la diffusion du traceur du sang au cerveau ont été calculées à partir de l'analyse de la relation dans le temps entre la radio activité du cerveau et celle du plasma. Les valeurs moyennes $\left(\mathrm{mL} . \mathrm{g}^{-1} . \mathrm{s}^{-1} \times 10^{6}\right)$ pour la pénétration dans 7 régions du cerveau $(n=10$ rats) variaient de $1.60 \pm 0.13$ (SE) à $1.86 \pm 0.33$ (respectivement pour le cortex et bulbe) et il n'y avait pas d'évidence d'une captation sélective par un transporteur ou une région particulière. Une néphrectomie antérieure à l'injection d'acide domö̈que provoquait une élévation du niveau plasmatique du traceur et de la captation par le cerveau. Les valeurs de Ki sont comparables à celles d'autres composés polaires tels le sucrose et indiquent que la barrière hémo-encéphalique limite considérablement la quantité de toxine qui pénètre dans le cerveau. L'intégrité de la barrière cérébrovasculaire et une fonction rénale normale de même que la dose absorbée sont importantes pour déterminer l'issue d'une ingestion accidentelle d'acide domoïque.
\end{abstract}

Can. J. Neurol. Sci. 1991; 18: 39-44

In December 1987, a major outbreak of human food poisoning in Canada was traced to the ingestion of cultivated mussels from Cardigan Bay, Prince Edward Island. These were contaminated with domoic acid, a neuroexcitatory toxin produced by the marine pennate diatom, Nitzchia pungens $f$. multiseries. ${ }^{1,2}$ Gastrointestinal disorders were a common occurrence, and in about one-third of the 145 confirmed cases, there were also marked neurological effects. These included confusion and disorientation, limbic seizures, and status epilipticus and coma in extreme cases. ${ }^{3,4}$ Some of the surviving patients still suffer from serious short-term memory impairment. 5 Post-mortem histopathology on brains of four patients who died demonstrated the marked bilateral neuronal destruction in hippocampus that is characteristic of neuroexcitatory amino acid poisoning. 6

The epidemiological studies of the outbreak ${ }^{7}$ indicated that more than 50,000 individuals consumed the mussels, most often in restaurants. A remarkable aspect of the poisoning episode is the relative paucity of manifest intoxications, considering the

From the Division of Biological Sciences, National Research Council of Canada, and the Laboratory Centre for Disease Control, Health and Welfare Canada, Ottawa

Received March 22, 1990. Accepted in final form September 6, 1990

Reprint requests to: Dr. E. Preston, Division of Biological Sciences, Bldg. M54, National Research Council, Ottawa, Ontario, Canada K1A 0R6 
likelihood that so many individuals had ingested a comparable meal and dosage. This would suggest that apart from ingested dose, additional factors remain to be investigated which might govern whether or not toxic effects would occur, e.g. degree of absorption from the gastrointestinal tract, liver detoxication and kidney excretion of the compound. Furthermore, certain pathological conditions would appear to modify the disposition and effects of domoic acid. Examination of the individual patients' histories revealed that all serious cases had a pre-existing condition such as diabetes, generalized atherosclerosis, chronic renal failure, amyloidosis, etc. ${ }^{7}$ The status of blood-brain barrier (BBB) function could be another critical factor since the manifestations of domoic acid intoxication, probably even the gastrointestinal symptoms, 8,9 stem primarily from actions within the CNS. The degree to which blood-borne domoic acid permeates the normal BBB by diffusion or transport is unknown. If the BBB largely restricts such uptake, cerebrovascular disorders that compromise barrier integrity could figure importantly in the relationship between absorbed dose and CNS effect.

In the following study we undertook to determine transfer constants characterizing penetration of domoic acid across the $\mathrm{BBB}$ of the rat. These measurements were obtained using domoic acid that was custom radiolabeled, and two radiotracer methods 10,11 that enable sensitive assessment of a very low degree of cerebrovascular permeability.

\section{METhOdS AND MATERIALS}

Purified domoic acid was obtained from Diagnostic Chemicals (Charlottetown, PEI). This was labeled with tritium by Amersham International (Buckinghamshire, England) to a specific activity of $5.2 \mathrm{Ci} / \mathrm{mmol}$ and radiochemical purity of $97 \%$. Tritiated sucrose was obtained with a specific activity of $13.4 \mathrm{Ci} / \mathrm{mmol}$ and purity of $99.5 \%$ from NEN Research Products (Dupont, NET-341).

Experiments were carried out on 36 male Sprague-Dawley rats, specific pathogen free and weighing 312-402 g. Preparative surgery and subsequent radiotracer procedures were carried out with the rat under sodium pentobarbital anesthesia (Somnotol, $60 \mathrm{mg} / \mathrm{kg}$ i.p.). Colonic temperature was maintained between $37.5-38.5^{\circ} \mathrm{C}$ by a thermosensor-controlled infrared lamp. For blood sampling and injections, tapered polyethylene cannulas (PE50) were inserted into the right femoral artery and vein. For some experiments, both common carotid arteries were surgically exposed. For other experiments, both kidneys were also exposed through an abdominal midline incision and each renal artery together with vein was tightly ligated with silk suture to cause a functional nephrectomy. The abdominal incision was then closed with sutures. When surgical procedures were complete, rats received sodium heparin solution (280 units i.v., Sigma Chemical Co.).

In the first series of experiments, the radiotracer method of Patlak et al ${ }^{11}$ was used to determine the transfer constant (Ki) for diffusion into brain of either ${ }^{3} \mathrm{H}$-sucrose or ${ }^{3} \mathrm{H}$-domoic acid. Rats received an intravenous saline injection $(1 \mathrm{~mL})$ containing a standard dose $(50 \mu \mathrm{Ci})$ of either tracer. This was permitted to circulate for a period of either $3,10,20$ or 30 min during which arterial blood was drawn by syringe pump at constant rate, preadjusted to provide a total sample of $0.8-1.2 \mathrm{~mL}$ when the period ended. The rat was then immediately decapitated and another blood sample collected from the severed neck. The brain was removed, placed on a moist filter paper and dissected bilaterally into seven regions. These were placed in tared vials, weighed and prepared for liquid scintillation counting by digestion overnight in $1.5 \mathrm{~mL}$ Soluene 350 (Packard). The two blood samples were centrifuged and 50 microlitre aliquots of plasma were also digested. Dimilume 30 fluor (Packard) was added to all digested samples, and these were stored 4 days to eliminate chemiluminescence before counting on a Beckman 6800 liquid scintillation counter. For each rat, the following values were obtained: (i) $\mathrm{C}_{\text {brain }}$ - the regional brain tracer concentration (dpm.g-1), (ii) $\int_{0}^{t} C_{\text {plasma }}{ }^{d t}$ - integral of plasma concentration with circulation time (dpm.mL-1.s) obtained by multiplying plasma tracer concentration $\left(\mathrm{C}_{\text {plasma }}\right)$ in the syringe-pump sample by circulation time $t$, in seconds, and (iii) $\mathrm{C}_{\text {final plasma }}$ - the final plasma concentration at time of decapitation (dpm.mL-1). These data from each rat were plotted on a graph with ordinate as $\mathrm{C}_{\text {brain }} / \mathrm{C}_{\text {final plasma }}$ and abscissa as $\int_{0}^{t} \mathrm{C}_{\text {plasma }} \mathrm{dt} / \mathrm{C}_{\text {final plasma. }}$ The regression line through the points is described by the equation:"1

$$
\mathrm{C}_{\text {brain }} / \mathrm{C}_{\text {final plasma }}=\mathrm{Ki} \cdot \int_{\mathrm{o}}^{t} \mathrm{C}_{\text {plasma }} \mathrm{d} / \mathrm{C}_{\text {final plasma }}+\mathrm{Vi}
$$

$\mathrm{Ki}$, the slope of the regression line, represents the transfer constant for blood to brain diffusion of tracer, and $\mathrm{Vi}$, the ordinate intercept, represents the volume of the plasma compartment for the tracer in dissected tissue plus volume of any parenchymal space with which the tracer rapidly equilibrated.

For further measurements of $\mathrm{Ki}$, based on the technique of Ohno et al, ${ }^{10}$ rats with femoral cannulas received an intravenous bolus injection of ${ }^{3} \mathrm{H}$-domoic acid which was allowed to circulate either 30 or $60 \mathrm{~min}$. Femoral arterial blood was sampled at constant rate by syringe pump during the 30 -min protocols, or periodically bled into microcentrifuge tubes ( 9 aliquots of 100 $\mu \mathrm{L}$ ) during 60 -min procedures. Five minutes before the end of the circulation period, the right common carotid artery was cannulated. At the end of the period, the heart was stopped with intravenous pentobarbital, the left common carotid artery ligated, both jugular veins severed, and $25 \mathrm{~mL}$ saline was perfused into the right common carotid at $\sim 120 \mathrm{~mm} \mathrm{Hg}$ pressure to clear the brain of blood. ${ }^{12}$ The rat was decapitated, and the brain and blood handled as above to determine the tracer concentration in brain parenchyma $\left(\mathrm{C}_{\text {paren }}, \mathrm{dpm} . \mathrm{g}^{-1}\right)$ and in arterial plasma $\left(\mathrm{C}_{\text {plasma }} \cdot \mathrm{dpm} \cdot \mathrm{mL}^{-1}\right)$. The time integral of plasma concentration $\left(\int_{0}^{t} C_{\text {plasma }} d t\right)$ in 30 -min experiments was obtained as described above. For the 60 -min experiments $C_{\text {plasma }}$ was plotted on paper against circulation time, and the area under the curve obtained. Regional transfer constants $(\mathrm{Ki})$ were calculated from the equation: 10

$$
\mathrm{Ki}=\mathrm{C}_{\text {paren }} / \int_{\mathrm{o}}^{t} \mathrm{C}_{\text {plasma }}{ }^{\mathrm{d}}
$$

\section{RESUlTS}

Figure 1 provides an example of the graphical data for radiotracer permeation into hippocampus of 10 rats that were injected with ${ }^{3} \mathrm{H}$-domoic acid, and of 10 animals injected with ${ }^{3} \mathrm{H}$ sucrose. Similar data plots were also obtained for 6 other brain regions. Regional transfer constants describing blood to brain diffusion of each tracer were obtained from slopes of the regression line through each data set, and are summarized in Table 1. 


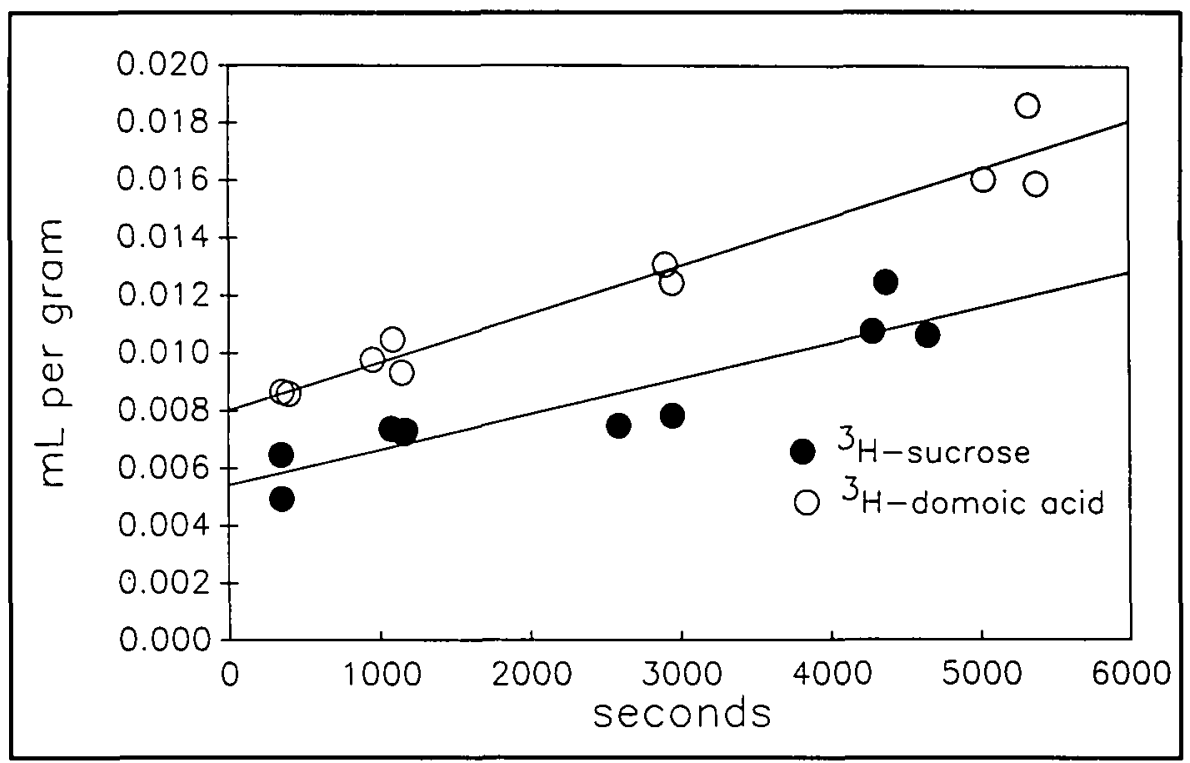

Figure I-Graphical analysis of the cerebrovascular permeation of blood-horne ${ }^{3} \mathrm{H}$-sucrose and ${ }_{3}^{3} \mathrm{H}$-domoic acid into hippocampus of anesthetized rats. Rats were decapitated 3,10, 20 or 30 min after intravenous injection. Each circle represents data from 1 animal ( $n=10$ per tracer). Ordinate: ratio of tracer level in hippocampus (dpm.g-l)lfinal plasma level (dpm. $\left.m L^{-1}\right)$. Abscissa: time integral of plasma level (dpm.s.mL.')lfinal plasma level.

Table 1: Transfer constants (Ki) for diffusion into brain of intravenously injected ${ }^{3} \mathrm{H}$-domoic acid or ${ }^{3} \mathrm{H}$-sucrose, and summed volume of the plasma space plus rapidly equilibrating space in parenchyma (Vi).

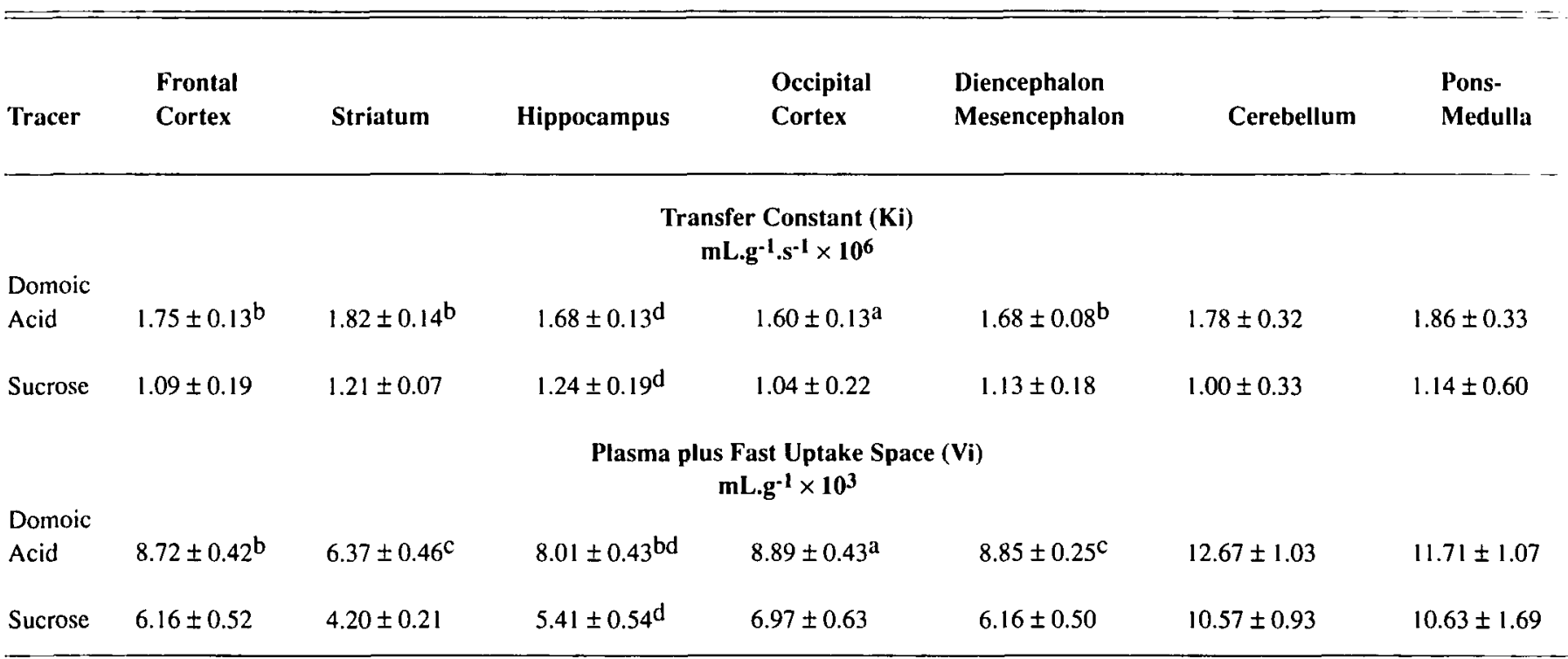

abc Values $\left(\bar{x} \pm\right.$ SEM shown) that are significantly higher than corresponding value for sucrose group $\left({ }^{a} p<0.05 b_{p}<0.01 ; c_{p}<0.001 ;\right.$ based on analysis of covariance).

$\mathrm{d}$ These values are the slopes and ordinate intercepts of the 2 data plots exampled in Figure 1. Rate of blood to brain tracer permeation is reflected in the slopes $(\mathrm{Ki})$ and total parenchymal accumulation after 3-30 min is indicated by increase in apparent plasma tracer space (data points, Figure 1) above the ordinate intercept ( $\mathrm{Vi}$, volume of the intravascular space plus rapidly equilibrating space). Actual levels of either tracer in dissected tissue ranged from 2682-19689 dpm per $g$ throughout the series, the highest values being obtained after 3 min circulation times when plasma levels and intravascular counts were very high relative to parenchyma. Final plasma levels ranged from $(227-1289) \times 10^{3} \mathrm{dpm} \cdot \mathrm{mL}^{-1}$. 
Mean values for $\mathrm{Ki}$ were higher for domoic acid than those for sucrose, indicating slightly greater permeability across the blood-brain barrier. Within the domoic acid group, it is noteworthy that $\mathrm{Ki}$ for uptake in hippocampus was not elevated relative to the values obtained for other brain regions. In most brain regions the values for $\mathrm{Vi}$ (Table 1) were higher for domoic acid compared to sucrose, indicating a larger volume of those space(s) with which the plasma tracer rapidly equilibrates.

In the second group of experiments, nephrectomized or sham-operated rats received an intravenous injection of ${ }^{3} \mathrm{H}$ domoic acid which was permitted to circulate for one hour. Figure 2 shows that, as expected, the profile of domoic acid in plasma of nephrectomized rats during the circulation period was greatly elevated compared to that in controls receiving the same dose. Table 2 summarizes the data from these two groups. The time integral of plasma tracer concentration in nephrectomized rats was elevated to 2.96 times the value in sham-operated controls. Nephrectomized rats consequently accumulated a larger amount of domoic acid in brain regions than controls (expressed as pg.g-1, Table 2). However, the increase in parenchymal uptake in nephrectomized rats was not in proportion to the higher plasma integral, and mean $\mathrm{Ki}$ values calculated from these data were significantly lower than control values.

From the mean tissue uptakes of ${ }^{3} \mathrm{H}$-domoic acid, Table 2, and knowledge of the specific activity and dose delivered, calculations were made to estimate the toxin level that might be expected in extracellular brain space assuming injection of a larger i.v. dose, $1 \mathrm{mg} / \mathrm{kg}$, a circulation time of $1 \mathrm{~h}$, and the extracellular space in brain being $15 \%$. The nanomolar concentrations obtained were as follows (control vs nephrectomized rats, respectively): frontal cortex $-191 \pm 7$ (SE) vs $376 \pm 32$; striatum - $154 \pm 8$ vs $218 \pm 7$; hippocampus $-204 \pm 13$ vs $392 \pm$ 26 ; occipital cortex $180 \pm 6$ vs $415 \pm 25$; diencephalon/mesencephalon $-171 \pm 12$ vs $320 \pm 18$; cerebellum $-215 \pm 16$ vs $484 \pm 36$; pons/medulla $-245 \pm 16$ vs $549 \pm 41$.
In the third group of experiments, anesthetized rats received ${ }^{3} \mathrm{H}$-domoic acid intravenously $(20 \mu \mathrm{Ci}$ per $100 \mathrm{~g}$; total dose of $12 \mu \mathrm{g} / \mathrm{kg}$ ) delivered either alone ( $\mathrm{n}=4 \mathrm{rats}$ ) or together with unlabeled toxin $(0.5 \mathrm{mg} / \mathrm{kg}, \mathrm{n}=4)$. After a 30 -min circulation period, the brain was perfused clear of intravascular tracer and $\mathrm{Ki}$ calculated from the ratio of parenchymal tracer to time-integrated plasma level. ${ }^{10}$ This forty-fold surplus of cold domoic acid in the bloodstream did not have a noteworthy influence on the magnitude of $\mathrm{Ki}$ for radiotracer permeation into brain. Regional Ki values (mL.g-1.s $\mathrm{s}^{-1} \times 10^{6}, \overline{\mathrm{x}} \pm \mathrm{SEM}$ ) were as follows for the two groups (tracer only vs tracer plus cold toxin, respectively): frontal cortex $-2.07 \pm 0.20$ vs $2.11 \pm 0.06$; striatum $1.97 \pm 0.17$ vs $2.00 \pm 0.10$; hippocampus $-2.43 \pm 0.18$ vs 2.61 \pm 0.17 ; occipital cortex $-2.06 \pm 0.18$ vs $2.35 \pm 0.15$; diencephalon/mesencephalon $-2.12 \pm 0.19$ vs $2.26 \pm 0.15$; cerebellum $-2.76 \pm 0.29$ vs $3.04 \pm 0.37$; pons/medulla $-3.40 \pm$ 0.32 vs $3.28 \pm 0.24$.

\section{Discussion}

The tricarboxylic structure of domoic acid favors the prediction that it circulates in the bloodstream in a charged (dissociated) hydrophilic state, and is thus hindered in permeating the BBB unless it undergoes carrier-mediated transport e.g. as for glucose or amino acids. The magnitudes of the Ki values (Table 1) confirm that while domoic acid uptake in brain is measurable following sufficient tracer dosage and circulation time, it penetrates very slowly across the cerebrovascular barrier. The Ki values for domoic acid are larger than those for sucrose, but this can be considered a minor difference. Published $\mathrm{Ki}$ values for sucrose permeation of the rat BBB often fall in the range of (210) $\times 10^{-6} \mathrm{~mL} \cdot \mathrm{g}^{-1} \cdot \mathrm{s}^{-1}$ (examples 13-16). The variation may partly reflect on the purity of the radiotracers that have been used. Only small amounts of radiolabeled impurities can substantially elevate $\mathrm{Ki}$ due to their preferential uptake in parenchyma

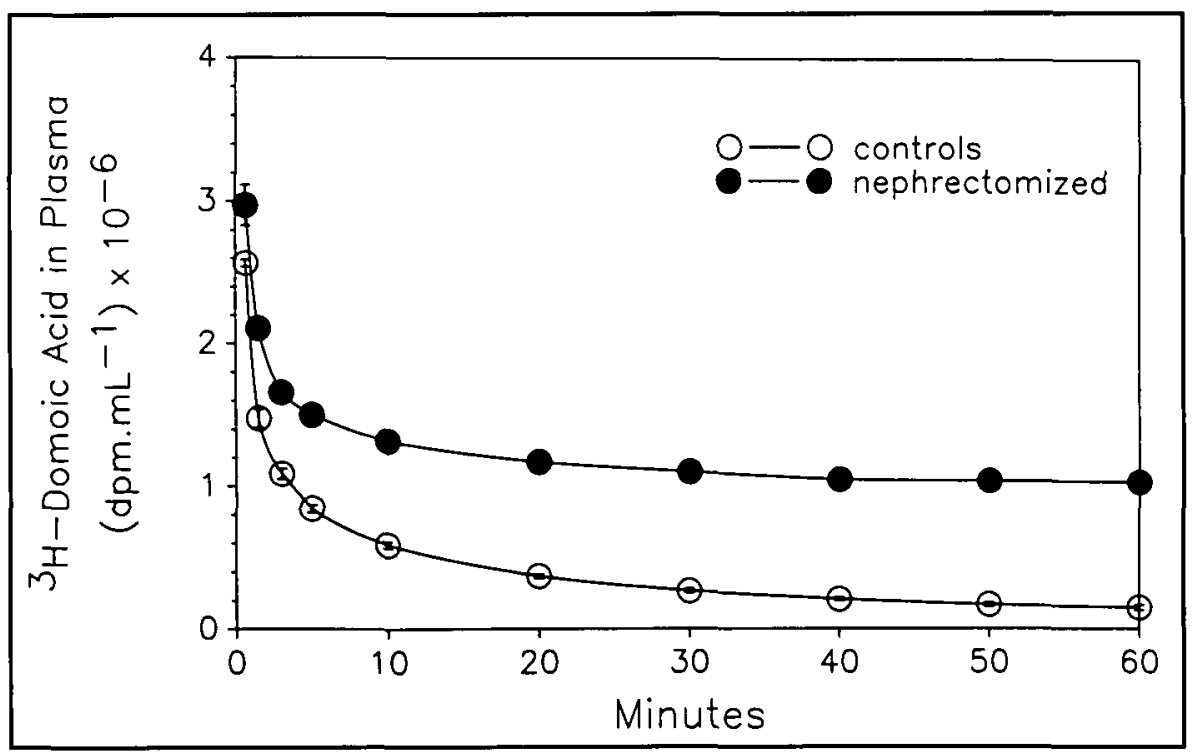

Figure 2 - Effect of prior nephrectomy or sham operation on the arterial plasma level of $3 \mathrm{H}$ domoic acid in anesthetized rats. Rats received an identical dose of tracer i.v., and blood samples were drawn periodically thereafter for $\ln (n=4$ nephrectomized rats and 4 controls.) 
relative to parent tracer e.g. as shown for ${ }^{14} \mathrm{C}$-sucrose ${ }^{15}$ and also discussed by Lefauconnier et al. ${ }^{17}$ The $\mathrm{Ki}$ values reported here are therefore more likely overestimates than underestimates of the true values under the experimental conditions involved. These values also contrast with those obtained for sucrose under circumstances when the $\mathrm{BBB}$ is experimentally rendered leaky, ${ }^{14.18}$ i.e. exceeding $200 \times 10^{-6} \mathrm{~mL}^{-g^{-1}} . \mathrm{s}^{-1}$

The low $\mathrm{Ki}$ values argue against the existence of a carrier mechanism for blood to brain movement of domoic acid, even in hippocampus for which $\mathrm{Ki}$ was not notably different relative to other regions. Moreover, injection of cold domoic acid did not lower Ki (see text, Results). A lowering would be anticipated if competition for a carrier took place between the miniscule quantity of labeled toxin in the bloodstream relative to the unlabeled toxin.

Comparison of the plasma profile of domoic acid over a $1 \mathrm{~h}$ period post-injection (Figure 2) in nephrectomized vs shamoperated rats showed that the kidneys played an important role in clearing the toxin from the bloodstream. Given the same dose, nephrectomized rats exhibited a much higher plasma tracer level, and uptake in brain was also augmented. However, it was not augmented to the same degree as the plasma concentration time integral, and the ratio of these measurements, which approximates $\mathrm{Ki}$, was lower (Table 2 ). The reason for this remains unexplained. The observation is in keeping with earlier published findings indicating that the BBB permeability is apparently diminished when kidney function is compromised. 19,20 However, one must also consider the possibility that plasma of nephrectomized rats might contain a gradually increasing amount of labeled metabolites. If less permeable than the parent tracer, these too could lower $\mathrm{Ki}$.

The data from sham-operated and nephrectomized rats, based on a tracer dose, was extrapolated upwards to provide an estimate of the extracellular toxin concentration to be expected in brain parenchyma (see text, Results) following circulation of a $1 \mathrm{mg} / \mathrm{kg}$ dose for a one hour period i.e. 154-245 nM in shamoperated rats. It is probable that lower i.v. doses would be pharmacologically effective in brain. Domoic acid is several times more potent than kainic acid as a neuroexcitant; ${ }^{21}$ and in vitro, concentrations of kainic acid of $10^{-7} \mathrm{M}(100 \mathrm{nM})$ or less can evoke depolarization and burst discharges of CA3 cells in hippocampal slices. 22 Data already published suggest the possibility that once such effects have been initiated, they in turn could lead to a secondary increase in the uptake of toxin into selective regions. For example, it was shown in rats that seizures induced by the excitotoxin, kainic acid, evoked blood-brain barrier leakiness which was especially marked in limbic structures. ${ }^{23}$

It is concluded that blood-borne domoic acid is largely restricted from crossing the blood-brain barrier into brain; transfer constant measurements show it to be similar in this respect to sucrose, mannitol and other substances recognized for their poor permeability. There was no indication of transport across the barrier, even in those regions e.g. hippocampus, known to be vulnerable to excitotoxin action. Nonetheless, a slow but measurable permeation of toxin into brain parenchyma does take place and clearance of toxin from the bloodstream by the kidneys together with normal barrier integrity would play a critical role in limiting the amount accumulating in brain. Pre-existing

Table 2: Effect of prior nephrectomy on plasma level and brain uptake of ${ }^{3} \mathbf{H}$-domoic acid in anesthetized rats.

Group

Dose (per Kg)

Final Plasma Level

Plasma Integral

Control

$\mu \mathrm{Ci} \quad \mu \mathrm{g}$

Nephrectomy

$121.5 \quad 7.28$

$121.5 \quad 7.28$

ng.mL-1

$4.02 \pm 0.49$

$27.73 \pm 0.62^{\mathrm{C}}$
dpm.s.mL-1 $\times 10^{-9}$

$1.66 \pm 0.07$

$4.92 \pm 0.11^{\mathrm{c}}$

\begin{tabular}{|c|c|c|c|c|c|c|}
\hline \multicolumn{7}{|c|}{ Tissue Uptake and Transfer Constant (Ki) } \\
\hline $\begin{array}{l}\text { Frontal } \\
\text { Cortex }\end{array}$ & Striatum & Hippocampus & $\begin{array}{c}\text { Occipital } \\
\text { Cortex }\end{array}$ & $\begin{array}{r}\text { Diencephalon } \\
\text { Mesencenhalon }\end{array}$ & Cerebellum & $\begin{array}{r}\text { Pons/ } \\
\text { Medulla }\end{array}$ \\
\hline
\end{tabular}

\begin{tabular}{|c|c|c|c|c|c|c|c|}
\hline \multirow[b]{2}{*}{ Control } & \multicolumn{6}{|c|}{ picograms per gram tissue } & \multirow[b]{2}{*}{$83 \pm 6$} \\
\hline & $65 \pm 2$ & $52 \pm 3$ & $69 \pm 5$ & $61 \pm 2$ & $58 \pm 4$ & $73 \pm 5$ & \\
\hline Nephrectomy & $128 \pm 11^{b}$ & $74 \pm 2^{b}$ & $133 \pm 9^{c}$ & $141 \pm 8^{\mathrm{c}}$ & $109 \pm 6^{c}$ & $164 \pm 12^{c}$ & $186 \pm 14^{c}$ \\
\hline \multicolumn{8}{|c|}{$\mathrm{Ki}\left(\mathrm{mL} \cdot \mathrm{g}^{-1} \cdot \mathrm{s}^{-1} \times 10^{6}\right)$} \\
\hline Control & $1.44 \pm 0.05$ & $1.17 \pm 0.03$ & $1.55 \pm 0.11$ & $1.36 \pm 0.05$ & $1.31 \pm 0.12$ & $1.63 \pm 0.13$ & $1.86 \pm 0.14$ \\
\hline Nephrectomy & $0.96 \pm 0.08^{b}$ & $0.56 \pm 0.02^{\mathrm{c}}$ & $1.00 \pm 0.06^{\mathrm{b}}$ & $1.06 \pm 0.07^{\mathrm{a}}$ & $0.82 \pm 0.04^{b}$ & $1.23 \pm 0.08^{a}$ & $1.40 \pm 0.08^{a}$ \\
\hline
\end{tabular}

After bilateral nephrectomy ( $n=4$ rats) or sham operation $\left(4\right.$ controls), a standard i.v. dose of ${ }^{3} \mathrm{H}$-domoic acid was permitted to circulate for 60 min. Radiotracer level was measured periodically in arterial plasma throughout $60 \mathrm{~min}$, and in brain parenchyma at the end of $60 \mathrm{~min}$ ( $v a l u e s$ are $\bar{x} \pm S E M$ ). Radiotracer counts in tissue e.g. $2563 \pm 167 \mathrm{dpm} . \mathrm{g}^{-1}$ for hippocampus (controls) were converted to $\mathrm{pg}^{-\mathrm{g}^{-1}}$ on the basis that the radiotracer specific activity was $16.7 \mu \mathrm{Ci}$ per $\mu \mathrm{g}$, equivalent to $37.1 \mathrm{dpm}$ per pg of domoic acid.

${ }^{a b c}$ Student's unpaired t-test, $p<0.05 ;<0.01 ;<0.001$ respectively for nephrectomy vs control. 
conditions that would compromise integrity of the blood-brain barrier or kidney excretion could be expected to have an important impact on the outcome of ingesting domoic acid.

\section{ACKNOWLEDGEMENTS}

We thank Nick Haas who carried out the surgeries for this study, and Sylvie Millaire and Dr. David O. Foster who assisted with the data analysis.

\section{REFERENCES}

1. Wright JLC, Boyd RK, DeFreitas ASW, et al. Identification of domoic acid, a neuroexcitatory amino acid, in toxic mussels from eastern Prince Edward Island. Can J Chem 1989; 67: $481-490$.

2. Wright JLC, Bird CJ, DeFreitas ASW, et al. Chemistry, biology, and toxicology of domoic acid and its isomers. Can Dis Wkly Rep 1990; 16(S1): 21-26.

3. Teitelbaum J. Clinical presentation of acute domoic acid poisoning. Can Dis Wkly Rep 1990; 16(S1): 5-6.

4. Teitelbaum J, Zatorre R, Carpenter $S$, et al. Neurological sequelae of domoic acid intoxication. Can Dis Wkly Rep 1990; 16(S1): 913.

5. Zatorre R. Memory loss following domoic acid intoxication from ingestion of toxic mussels. Can Dis Wkly Rep 1990; 16(S1): 9698.

6. Carpenter S. Human neuropathology of encephalopathic toxic mussel poisoning. Can Dis Wkly Rep 1990; 16(S1): 72-73.

7. Perl TM, Bedard L, Kosatsky T, et al. Amnesic shellfish poisoning: a new clinical syndrome due to domoic acid; gastrointestinal and neurologic illness related to mussels from Prince Edward Island. Can Dis Wkly Rep 1990; 16(S1): 7-8.

8. Olney JW. Excitotoxicity: an overview. Can Dis Wkly Rep 1990; 16(S1): 46-58.

9. Galvin G, Bose R, Pinsky C. Gastrointestinal effects of contaminated mussels and putative antidotes thereof. Can Dis Wkly Rep 1990; 16(S1): 105-109.

10. Ohno K, Pettigrew KD, Rapoport SI. Lower limits of cerebrovascular permeability to nonelectrolytes in the conscious rat. Am J Physiol 1978; 235: H299-H307.
11. Patlak CS, Blasberg RG, Fenstermacher JD. Graphical evaluation of blood to brain transfer constants from multiple-time uptake data. J Cereb Blood Flow Metab 1983; 3: 1-32.

12. Preston E, Allen M, Haas N. A modified method for measurement of radiotracer permeation across the rat blood-brain barrier: the problem of correcting brain uptake for intravascular tracer. $\mathbf{J}$ Neurosci Methods 1983; 9: 45-55.

13. Williams WM, Platner J, Michaelson SM. Effect of $2450 \mathrm{MHz}$ microwave energy on the blood-brain barrier to hydrophilic molecules. III. Effect on the permeability to ${ }^{14} \mathrm{C}$-sucrose. Brain Res Rev 1984; 7: 183-190.

14. Rapoport SI, Ohno K, Fredericks WR, et al. Regional cerebrovascular permeability to ${ }^{14} \mathrm{C}$-sucrose after osmotic opening of the blood-brain barrier. Brain Res 1978; 150: 653-657.

15. Preston E, Haas N. Defining the lower limits of blood-brain barrier permeability: factors affecting the magnitude and interpretation of permeability-area products. J Neurosci Res 1986; 16: 709719.

16. Gross PM, Teasdale GM, Graham DI, et al. Intra-arterial histamine increases blood-brain transport in rats. Am J Physiol 1982; 243: $\mathrm{H} 307-\mathrm{H} 317$

17. Lefauconnier JM, Tayarani Y, Bernard G. Blood-brain barrier permeability to excitatory amino acids. In: Excitatory Amino Acids and Epilepsy. Schwarcz R, Ben-Ari Y, eds, New York: Plenum Press 1986: 191-198.

18. Rapoport SI, Fredericks WR, Ohno K, et al. Quantitative aspects of reversible osmotic opening of the blood-brain barrier. Am J Physiol 1980; 221: 214-217.

19. Lin TH, Sawada Y, Sugiyama Y, et al. Inhibition of blood-brain barrier permeability to DL-propranolol by serum from acute renal failure rats. Biochem Pharmacol 1987; 36: 3425-3431.

20. Preston E, Haas N, Allen M. Reduced permeation of ${ }^{14} \mathrm{C}$-sucrose, ${ }^{3} \mathrm{H}$-mannitol and ${ }^{3} \mathrm{H}$-inulin across blood-brain barrier in nephrectomized rats. Brain Res Bull 1984; 122: 133-136.

21. Coyle JT. Neurotoxic action of kainic acid. J Neurochem 1983; 41: $1-11$.

22. Robinson JH, Deadwyler SA. Kainic acid produces depolarization of CA3 pyramidal cells in the in vitro hippocampal slice. Brain Res 1981; 221: 117-127

23. Zucker DK, Wooten GF, Lothman EW. Blood-brain barrier changes with kainic acid-induced limbic seizures. Exp Neurol 1983; 79: 422-433. 